\title{
Stemness Potency of Human Gingival Cells-Application in Anticancer Therapies and Clinical Trials
}

\author{
Katarzyna Stefańska ${ }^{1}{ }^{\circledR}$, Katarzyna Mehr ${ }^{2}$, Maria Wieczorkiewicz ${ }^{3}{ }^{\circledR}$, Magdalena Kulus ${ }^{4}{ }^{(}$,

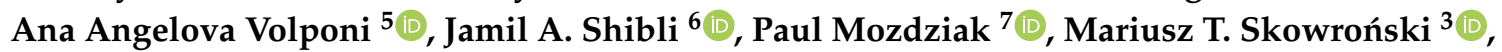 \\ Paweł Antosik ${ }^{4}$, Jędrzej M. Jaśkowski ${ }^{8}$, Hanna Piotrowska-Kempisty ${ }^{9}$, Bartosz Kempisty ${ }^{4,10, *}$ \\ and Marta Dyszkiewicz-Konwińska ${ }^{10,11}$ (1)
}

1 Department of Histology and Embryology, Poznan University of Medical Sciences, 6 Święcickiego St., 60-781 Poznan, Poland; k.stefanska94@o2.pl

2 Department of Gerostomatology and Pathology of Oral Cavity, Poznan University of Medical Sciences, 70 Bukowska St., 60-812 Poznan, Poland; katarzynamehr@gmail.com

3 Department of Basic and Preclinical Sciences, Institute of Veterinary Medicine, Nicolaus Copernicus University in Torun, 7 Gagarina St., 87-100 Torun, Poland; maria.wieczorkiewicz@umk.pl (M.W.); skowron@umk.pl (M.T.S.)

4 Department of Veterinary Surgery, Institute of Veterinary Medicine, Nicolaus Copernicus University in Torun, 7 Gagarina St., 87-100 Torun, Poland; magdalena.kulus@umk.pl (M.K.); pantosik@umk.pl (P.A.)

5 Centre for Craniofacial and Regenerative Biology, Dental Institute, King's College London, Strand, London WC2R 2LS, UK; ana.angelova@kcl.ac.uk

6 Department of Periodontology and Oral Implantology, Dental Research Division, Guarulhos University, Guarulhos, R. Eng. Prestes Maia, 88-Centro, São Paulo 07023-070, Brazil; jashibli@yahoo.com

7 Physiology Graduate Program, North Carolina State University, Campus Box 7608, Raleigh, NC 27695-7608, USA; pemozdzi@ncsu.edu

8 Department of Diagnostics and Clinical Sciences, Institute of Veterinary Medicine, Nicolaus Copernicus University in Torun, 7 Gagarina St., 87-100 Torun, Poland; jmjaskowski@umk.pl

9 Department of Toxicology, Poznan University of Medical Sciences, 30 Dojazd St., 60-631 Poznan, Poland; hpiotrow@ump.edu.pl

10 Department of Anatomy, Poznan University of Medical Sciences, 6 Święcickiego St., 60-781 Poznan, Poland; m.dyszkiewicz@ump.edu.pl

11 Department of Biomaterials and Experimental Dentistry, Poznan University of Medical Sciences, 70 Bukowska St., 60-812 Poznan, Poland

* Correspondence: bkempisty@ump.edu.pl; Tel./Fax: +48-61-8546565

Received: 7 July 2020; Accepted: 14 August 2020; Published: 18 August 2020

Abstract: Gingivae, as the part of periodontium, are involved in tooth support and possess the ability to heal rapidly, without scar formation. Recently, dental tissues have been identified as a potential source of mesenchymal stem cells (MSCs) and several populations of MSCs were isolated from the orofacial region, including gingival mesenchymal stem cells (GMSCs). GMSCs exhibit robust immunomodulatory and differentiation potential and are easily obtainable, which make them promising candidates for cellular therapies. Apart from being tested for application in immunologic- and inflammatory-related disorders and various tissue regeneration, GMSCs promise to be a valuable tool in cancer treatment, especially in tongue squamous cell carcinoma (TSCC) with the use of targeted therapy, since GMSCs are able to selectively migrate towards the cancerous cells both in vitro and in vivo. In addition to their ability to uptake and release anti-neoplastic drugs, GMSCs may be transduced with apoptosis-inducing factors and used for cancer growth inhibition. Moreover, GMSCs, as most mammalian cells, secrete exosomes, which are a subset of extracellular vesicles with a diameter of 40-160 nm, containing DNA, RNA, lipids, metabolites, and proteins. Such GMSCs-derived exosomes may be useful therapeutic tool in cell-free therapy, as well as their 
culture medium. GMSCs exhibit molecular and stem-cell properties that make them well suited in preclinical and clinical studies.

Keywords: gingiva; gingival mesenchymal stem cells; mesenchymal stem cells; mesenchymal stromal cells; cancer; exosomes

\section{Introduction}

Mesenchymal stem cells (MSCs) comprise a heterogenous subset of stromal cells that have fibroblast-like morphology, form colonies in vitro, and proliferate as plastic-adherent cells [1]. MSCs were isolated for the first time by Friedenstein et al. [2] from the bone marrow, defined as colony-forming unit fibroblasts (CFU-Fs) and were demonstrated to possess self-renewal abilities. Subsequently, their multilineage differentiation potential was reported [3], suggesting that MSCs may be utilized in cellular therapies and regenerative medicine. Since then, MSCs have been isolated from various tissues, such as adipose tissue [4], placenta [5], amniotic fluid [6], fetal liver [7], or umbilical cord [8]. Although embryonic stem cells (ESCs) are pluripotent, they possess the ability to differentiate into all three primary germ layers, and their acquisition is ethically controversial, since they are derived from the inner cell mass of the preimplantation blastocyst [9]. MSCs utilization is not burdened with such concerns, as they can be obtained from adult tissues.

The orofacial region gained lot of interest as a potential source of MSCs as well. To date, eight distinct populations of dental-derived MSCs have been obtained, with dental pulp stem cells (DPSCs) being isolated as first by Gronthos et al. [10]. Subsequent studies led to isolation of stem cells from human exfoliated deciduous teeth (SHED) [11], periodontal ligament stem cells (PDLSCs) [12], dental follicle progenitor cells (DFPCs) [13], alveolar bone marrow stromal cells (ABMSCs) [14], stem cells from the apical papilla (SCAP) [15], tooth germ progenitor cells (TGPCs) [16], and gingival mesenchymal stem cells (GMSCs) [17].

The gingiva, as the majority of the periodontal tissues, arises from the neural crest ectomesenchymal origin (N-GMSCs); however, Xu et al. indicated that about $10 \%$ of GMSCs is derived from mesoderm (M-GMSCs) [18]. Compared to M-GMSCs, N-GMSCs preferably differentiate into neural cells, accompanied by an increase in nestin, neurofilament M (NF-09), and $\beta$-tubulin III expression and the elevated expression of Fas ligand (FasL). However, both subpopulations show no difference in osteogenic and adipogenic differentiation. In terms of histological structure, the gingiva consists of connective tissue and epithelium and, as a part of the periodontium, is involved in tooth support, surrounding the tooth and being attached to the alveolar bone, forming the gingival attachment [19]. The gingival tissue seems to be a particularly attractive source of stem cells, given its fast regeneration after injury without scar formation, compared to the skin healing abilities, and the fact that obtaining it is minimally invasive for the patient [20]. Moreover, it may be used in autologous transplant, with no need for search for a matching donor.

Mesenchymal stem cells have been a major focus of regenerative medicine in recent years. They offer a promise to manage diseases such as rheumatoid arthritis, systemic lupus erythematosus, multiple sclerosis, diabetes mellitus, neurological disorders, and many others [21]. Thus, there is constant ongoing search for easily available MSCs that could be applied in clinical environment, and GMSCs seem to fulfill those requirements. Therefore, the objective of this review is to describe the methods of isolation and cultivation of human gingival cells, their molecular properties and plasticity, and possible clinical application.

\section{Methods of GMSCs Isolation and Cultivation}

For GMSCs isolation, gingival tissue samples are obtained during standard dental procedures, during which they constitute biological waste and are then used for research, or as a targeted procedure, 
e.g., as a "gingiva punch." Such tissue is then deprived of epithelium and the remaining connective tissue is either minced and enzymatically digested or cut into smaller pieces, in the explant method. In case of the explant method, the gingiva is minced with a sterile scalpel and such obtained tissue pieces are placed in tissue culture dishes, for plastic-adherent cells outgrowth. The basal media used for the culture varied amongst researchers, including Minimum Essential Medium $\alpha(\alpha$-MEM) [22,23] or Dulbecco's Modified Eagle's Medium (DMEM) [24,25]. In most cases, the media were supplemented with fetal bovine serum (FBS) of different concentrations [22,24]. However, some investigators utilized fetal calf serum (FCS) [23,25]. In a study by Fawzy El-Sayed et al. [23], the magnetic activated cell sorting (MACS) was used to obtain STRO-1 positive population of GMSCs after initial isolation. As a result, they obtained two distinctive populations of gingiva-derived cells; STRO-1/MACS+ cells were positive for mesenchymal stromal cell markers defined by ISCT [26] and exhibited multilineage differentiation potential and CFU (colony forming unit) capacity, whereas STRO-1/MACS- cell fraction expressed hematopoietic markers, such as CD34 or CD45, and multilineage differentiation potential was not evident, suggesting that this population of cells lack many of stem cell properties [23]. Importantly, Rao et al. [27] demonstrated, that STRO-1 expression in GMSCs decreased with an increasing passage number, suggesting that this marker may be useful for undifferentiated GMSCs isolation.

In case of the other aforementioned method, the tissue samples are diced and digested in enzymatic solutions of various compositions and then filtered through strainers to obtain single cell suspensions. The enzymes used by the researchers included collagenase IV [17,28], collagenase I [29], or a combination of various types of collagenase and Dispase [30-32]. Amongst the researchers using the enzymatic method, Ge et al. [31] attempted to isolate MSCs from inflamed gingival tissue, taking into consideration its abundance and accessibility. Ge et al. [31] discovered that such GMSCs exhibited proliferative potential and expressed markers characteristic for MSCs, therefore suggesting that inflamed gingiva may provide a valuable source of MSCs instead of being discarded as a biological waste [31]. In case of all aforementioned studies, the in vitro culture was conducted in a humidified tissue culture incubator with $5 \% \mathrm{CO}_{2}$ at $37^{\circ} \mathrm{C}$. A more detailed overview of GMSCs isolation via enzymatic and explant method is provided in Table 1. 
Table 1. Overview of gingival mesenchymal stem cells (GMSCs) isolation and culture methods.

\begin{tabular}{|c|c|c|c|c|c|}
\hline $\begin{array}{l}\text { Isolation } \\
\text { Method }\end{array}$ & Author & $\begin{array}{l}\text { Publication } \\
\text { Date }\end{array}$ & $\begin{array}{c}\text { Composition of Culture } \\
\text { Medium }\end{array}$ & $\begin{array}{l}\text { Enzymes Used } \\
\text { for Digestion }\end{array}$ & Time of Digestion \\
\hline \multirow{4}{*}{$\begin{array}{l}\text { Explant } \\
\text { method }\end{array}$} & El-Bialy et al. [24] & 2014 & $\begin{array}{c}\text { DMEM, } 10 \% \text { FBS, } 100 \mathrm{U} / \mathrm{mL} \\
\text { penicillin, } 100 \mu \mathrm{g} / \mathrm{mL} \\
\text { streptomycin }\end{array}$ & - & - \\
\hline & $\begin{array}{c}\text { Fawzy } \\
\text { El-Sayed et al. [23] }\end{array}$ & 2015 & $\begin{array}{c}\alpha-\mathrm{MEM}, 15 \% \text { FCS, } 400 \\
\mathrm{mM} / \mathrm{mL} \text { L-glutamine, } 100 \\
\mathrm{U} / \mathrm{mL} \text { penicillin, } 100 \mu \mathrm{g} / \mathrm{mL} \\
\text { streptomycin, } 1 \% \\
\text { amphotericin }\end{array}$ & - & - \\
\hline & Fournier et al. [25] & 2010 & $\begin{array}{c}\text { DMEM, 20\% FCS, } 100 \mu \mathrm{g} / \mathrm{mL} \\
\text { penicillin, } 100 \mu \mathrm{g} / \mathrm{mL} \\
\text { streptomycin, } 2 \mathrm{ng} / \mathrm{mL} \\
\text { amphotericin }\end{array}$ & - & - \\
\hline & Mitrano et al. [22] & 2010 & $\begin{array}{c}\alpha \text {-MEM, 10\% FBS, } 1 \% \\
\text { penicillin, streptomycin, } \\
\text { amphotericin }\end{array}$ & - & - \\
\hline \multirow{6}{*}{$\begin{array}{l}\text { Enzymatic } \\
\text { method }\end{array}$} & Gao et al. [28] & 2014 & $\alpha$-MEM, $10 \%$ FBS & $\begin{array}{c}4 \mathrm{mg} / \mathrm{mL} \\
\text { collagenase IV }\end{array}$ & $2 \mathrm{~h}$ at $37^{\circ} \mathrm{C}$ \\
\hline & Ge et al. [31] & 2012 & $\begin{array}{c}\alpha \text {-MEM, } 20 \% \text { FCS, } 2 \mathrm{mM} \\
\text { L-glutamine, } 100 \mu \mathrm{M} \\
\text { L-ascorbate-2-phosphate, } \\
1 \mathrm{mM} \text { sodium pyruvate, } 50 \\
\mathrm{U} / \mathrm{mL} \text { penicillin, } 50 \mu \mathrm{g} / \mathrm{mL} \\
\text { streptomycin, } 2.5 \mu \mathrm{g} / \mathrm{mL} \\
\text { amphotericin }\end{array}$ & $\begin{array}{c}3 \mathrm{mg} / \mathrm{mL} \\
\text { collagenase I, } \\
4 \mathrm{mg} / \mathrm{mL} \\
\text { Dispase II }\end{array}$ & $50 \mathrm{~min}$ at $37^{\circ} \mathrm{C}$ \\
\hline & Jin et al. [32] & 2015 & $\begin{array}{l}\alpha \text {-MEM, } 15 \% \text { FBS, } 100 \mathrm{U} / \mathrm{mL} \\
\text { penicillin, } 100 \mu \mathrm{g} / \mathrm{mL} \\
\text { streptomycin, } 200 \mathrm{mM} \\
\text { L-glutamine, } 10 \mathrm{mM} \text { ascorbic } \\
\text { acid 2-phosphate }\end{array}$ & $\begin{array}{l}2 \mathrm{mg} / \mathrm{mL} \\
\text { collagenase IV, } \\
1 \mathrm{mg} / \mathrm{mL} \\
\text { Dispase }\end{array}$ & $\begin{array}{c}30 \text { at } 37^{\circ} \mathrm{C} \text { (fraction } \\
\text { discarded) } 90 \text { min at } 37 \\
{ }^{\circ} \mathrm{C} \text { (fraction seeded) }\end{array}$ \\
\hline & Tang et al. [29] & 2011 & $\begin{array}{c}\text { DMEM, } 10 \% \text { FBS, } \\
0.292 \mathrm{mg} / \mathrm{mL} \text { glutamine, } 100 \\
\mathrm{U} / \mathrm{mL} \text { penicillin, } 100 \mu \mathrm{g} / \mathrm{mL} \\
\text { streptomycin }\end{array}$ & $\begin{array}{l}0.66 \mathrm{mg} / \mathrm{mL} \\
\text { collagenase I }\end{array}$ & $50 \mathrm{~min}$ at $37^{\circ} \mathrm{C}$ \\
\hline & Tomar et al. [30] & 2010 & $\alpha$-MEM, $10 \%$ FCS & $\begin{array}{c}0.1 \% \\
\text { collagenase, } \\
0.2 \% \text { Dispase }\end{array}$ & $\begin{array}{c}15 \mathrm{~min} \text { at } 37^{\circ} \mathrm{C} \\
\text { (fraction discarded) } 5 \\
\text { min at } 37^{\circ} \mathrm{C} 10 \mathrm{~min} \text { at } \\
37^{\circ} \mathrm{C} 15 \mathrm{~min} \text { at } 37^{\circ} \mathrm{C} \\
\text { (fractions pooled } \\
\text { and seeded) }\end{array}$ \\
\hline & Zhang et al. [17] & 2009 & $\begin{array}{c}\alpha \text {-MEM, } 10 \% \text { FBS, } 100 \mathrm{U} / \mathrm{mL} \\
\text { penicillin, } 100 \mu \mathrm{g} / \mathrm{mL} \\
\text { streptomycin, } 2 \mathrm{mM} \\
\text { L-glutamine, } 100 \mathrm{mM} \\
\text { nonessential amino acids }\end{array}$ & $\begin{array}{c}4 \mathrm{mg} / \mathrm{mL} \\
\text { collagenase IV }\end{array}$ & $2 \mathrm{~h}$ at $37^{\circ} \mathrm{C}$ \\
\hline
\end{tabular}

\section{Stemness Properties and Differentiation Ability of GMSCs}

GMSCs fulfill the minimal criteria to be considered as mesenchymal stem cells, according to the International Society for Cellular Therapy (ISCT) [26], meaning they are plastic-adherent in standard culture conditions, express specific surface antigens, which include CD105 (Endoglin), CD73, and, CD90 (Thy-1), do not express CD45, CD34, CD14, CD11b, CD79 $\alpha$, CD19, and HLA-II (human leukocyte antigen II), and are able to differentiate into osteoblasts, chondroblasts, and adipocytes [26]. Many investigators have decided to expand this list of markers, revealing that GMSCs also express CD29 (Integrin beta 1) [17,30], CD44 [22,25,30,32], CD146 [29], and even proteins considered as markers of pluripotency or embryonic stem cell markers, namely, Oct-4 (octamer-binding transcription factor 4), STRO-1, SSEA-4 (stage-specific embryonic antigen 4), and Nanog [33,34]. Primary cultures of GMSCs comprise uniformly homogenous population of spindle-shaped fibroblast-like cells, contrary to bone marrow-derived MSCs (BM-MSCs), which require two to three passages to become homogenous [30]. They are also more proliferative and genetically stable than BM-MSCs, show normal karyotype and 
are nontumorigenic in both early and late passages and expand independently on external growth factors [30].

Osteogenic differentiation was carried out in a number of studies by conducting GMSCs culture in osteoinductive medium with addition of dexamethasone, ascorbic acid, and $\beta$-glycerophosphate (among others) [22,25,28,29,32,35-37]. The results of differentiation were confirmed with Alizarin Red $\mathrm{S}$ staining to detect calcified deposits in culture, alkaline phosphatase (ALP) activity assay, and gene expression analysis of bone specific markers-Runx2 (Runt-related transcription factor 2), collagen I, ALP, osteocalcin (OCN), and bone sialoprotein (BSP) [22,25,28,29,32,35-37]. Moreover, GMSCs exhibited higher osteogenic potential than BM-MSCs, as indicated by Sun et al. [36].

In case of adipogenic differentiation, the culture medium was supplemented with 1-methyl3-isobutylxanthine, indomethacin dexamethasone, insulin, and L-glutamine, and the presence of lipid droplets was evaluated with oil red O staining $([22,25]$ among others). Interestingly, the addition of muscone, one of the main components of natural musk, to the culture medium enhanced the adipogenic differentiation of GMSCs, whereas the osteogenic differentiation was decreased when the inhibition of the $\mathrm{Wnt} / \beta$-catenin signaling pathway was present [38].

For chondrogenic differentiation, the culture medium was supplemented with different combinations of TGF- $\beta$, dexamethasone, ascorbic acid, insulin, bone morphogenetic protein 6 , and insulin-transferrin selenium acid [22,25]. The results of differentiation were confirmed by safranin O staining for glycosaminoglycans [22] and toluidine blue, which highlights the acid proteoglycans [25].

Apart from this trilineage differentiation potential, the ability of GMSCs to transform into neurons and endothelial cells was demonstrated by Zhang et al. [17]. They reported that after 1 week culture in endothelial growth medium, GMSCs started to express CD31 (PECAM-1), which is a marker for endothelial cells. Importantly, under normal culture conditions, its expression was not observed. After the cultivation in neuroinductive conditions, GMSCs were positive for glial fibrillary acidic protein (GFAP), neurofilament 160/200 (NF-M), and $\beta$-tubulin III [17]. On the contrary, Marynka-Kalmani et al. [39] reported a decrease in $\beta$-tubulin III and glial fibrillary acidic protein expression and induction of NeuN and MAP2 (microtubule associated protein 2) expression. In the same study, GMSCs subjected to glial differentiation regimen were shown to induce neuritogenesis and support PC12 cells survival [39]. Neurogenic differentiation of GMSCs could be enhanced by low-intensity pulsed ultrasound (LIPUS) [24], hypoxia preconditioning [40] or treatment with cannabidiol (CBD) [41]. Rao et al. [42], on the other hand, successfully differentiated GMSCs encapsulated in the bioconjugated protein hydrogel (3D) into neuronal lineage, which was confirmed by presence of Nissl bodies, as well as the elevated expression of nestin, $\beta$-tubulin III, and MAP2.

To accomplish myogenic differentiation, GMSCs were encapsulated in alginate microspheres containing growth factors and cultured in medium with the addition of dexamethasone, ascorbic acid, sodium pyruvate, forskolin, and bFGF [43]. After 2 weeks of in vitro cultivation, the morphology of GMSCs changed towards myogenic cells; after 4 weeks, immunofluorescence staining revealed presence of myogenic markers, such as Myosin II (MF20), MyoD, and Myf5, which was confirmed by subsequent gene expression analysis [43]. The differentiation potential of GMSCs is presented in Figure 1. 


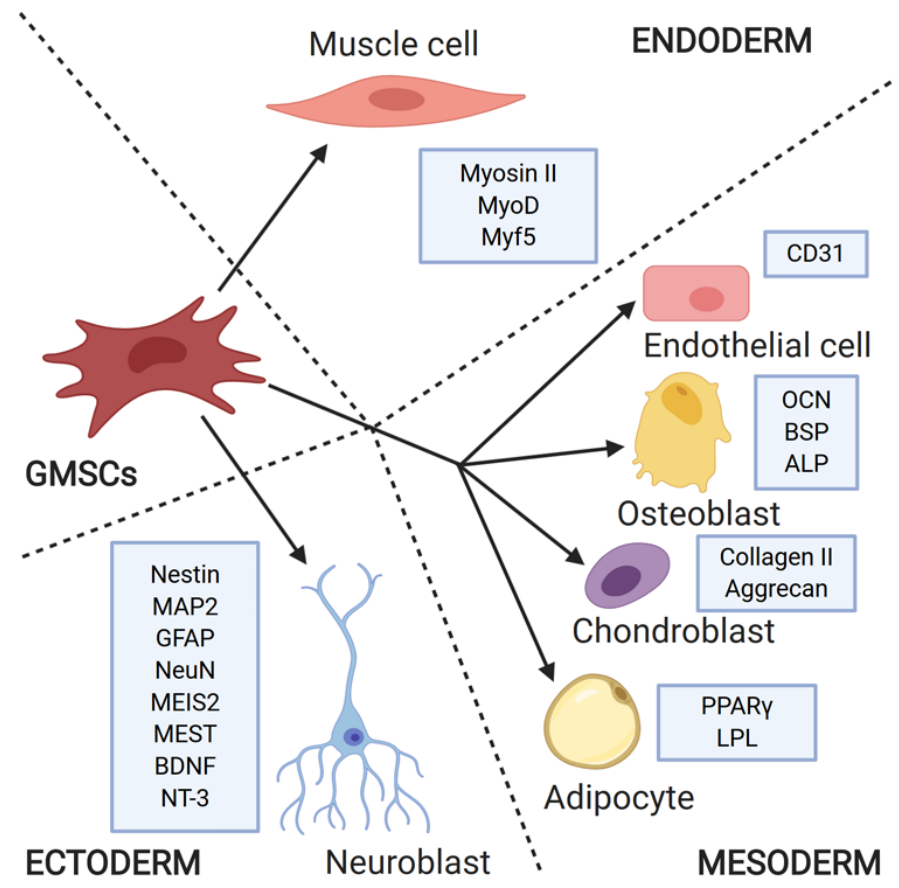

Figure 1. GMSCs were differentiated into lineages derived from all three primary germ layers, which was confirmed with the presence of cell-specific markers. Abbreviations: MyoD—myoblast determination protein 1; Myf5-myogenic factor 5; OCN-osteocalcin, BSP-bone sialoprotein; ALP—alkaline phosphatase; PPAR $\gamma$ - peroxisome proliferator-activated receptor $\gamma$; LPL-lipoprotein lipase; MAP2 — microtubule associated protein 2; GFAP—glial fibrillary acidic protein; NeuN—neuronal nuclei; MEST-mesoderm-specific transcript homolog protein; BDNF-brain-derived neurotrophic factor; NT-3-neurotrophin 3. Created with BioRender.

\section{Immunomodulatory Properties}

Apart from their self-renewal and differentiation capacities, MSCs also exhibit a broad range of immunomodulatory properties, which may be exerted by direct cell-to-cell contact or in paracrine manner, via soluble factors production (e.g., IL-1 (interleukin 1), IL-6, IL-10, indoleamine 2,3-dioxygenase (IDO), nitric oxide (NO), transforming growth factor $\beta 1$ (TGF $\beta 1$ ), and prostaglandin E2 (PGE2)) [44]. Importantly, such immunoregulation may occur in various ways, depending on the level of inflammation in the surrounding environment, as indicated by Li et al. [45]. When activated T cells produced low levels of inflammatory IFN $\gamma$ (interferon $\gamma$ ) and TNF $\alpha$ (tumor necrosis factor $\alpha)$, MSCs enhanced their proliferation, supporting the immune reaction. On the contrary, the higher amount of these cytokines enhanced immunosuppressive properties of MSCs [45].

Zhang et al. [17] reported that GMSCs inhibited peripheral mononuclear blood cell (PBMC) proliferation and cytokine secretion in response to mitogen stimulation. Their results suggested that IDO (that is not constitutively expressed by GMSCs) and IL-10, but not TGF $\beta 1$, COX2 or iNOS, were involved in this immunosuppression. Moreover, the secretion of IDO and IL-10 by GMSCs was stimulated by IFN $\gamma$ [17]. Similar results were obtained by Davies et al. [46] in oral mucosal progenitor cells, who also reported IDO upregulation in these cells in response to IFN $\gamma$ stimulation. Moreover, Jiang et al. [47] indicated that hypoxia enhanced IL-10 production and FasL (Fas ligand) expression in GMSCs, which resulted in increased PBMCs apoptosis. The mechanism of FasL/Fas-mediated T cell apoptosis inflicted by MSCs (BM-MSCs, specifically) was described by Akiyama et al. [48], and FasL expression in GMSCs derived of neural crest ectomesenchyme was also reported by $\mathrm{Xu}$ et al. [18].

Su et al. [49] reported using GMSCs in managing hapten-induced murine contact hypersensitivity (CHS) and observed a reduced infiltration of dendritic cells, CD8+ T cells, and Th17 effector cells in allergic areas, while infiltration of Tregs was enhanced. A number of mast cells, which are critical in allergic and inflammatory disorders [50], as well as the percentage of degranulated mast cells, were also 
decreased in response to the treatment. Such immunosuppressive effect on dendritic and mast cells was ascribed to $\mathrm{PGE}_{2}$, but not IL-10, TGF $\beta 1$, or IDO, production [49]. GMSCs were also demonstrated to elicit M2 polarization of macrophages and enhance cutaneous wound healing, which was due to the secretion of soluble factors by GMSCs, namely, IL-6 and GM-CSF [51]. After coculture with GMSCs, macrophages exhibited an increased expression of mannose receptor (CD206) and secreted IL-6 and IL-10. Moreover, their ability to induce Th17 cell expansion was reduced, as well as their production of $\mathrm{TNF} \alpha$, which was hypothesized to be due to impaired activation of NFKB p50 [51]. Zhao et al. [52] investigated the influence of GMSCs on T cell-mediated bone marrow failure in a mouse model. GMSCs reduced infiltration of CD8+ T cells, Th1 and Th17 cells, while differentiation of CD4+FOXP3+ Tregs was enhanced in lymph nodes. In addition, the serum levels of inflammatory cytokines, such as TNF $\alpha$, IFN $\gamma$, or IL-6, decreased with an increase of anti-inflammatory IL-10, indicating that bone marrow failure was attenuated [52]. The schematic immunomodulatory activity of GMSCs is presented in Figure 2.

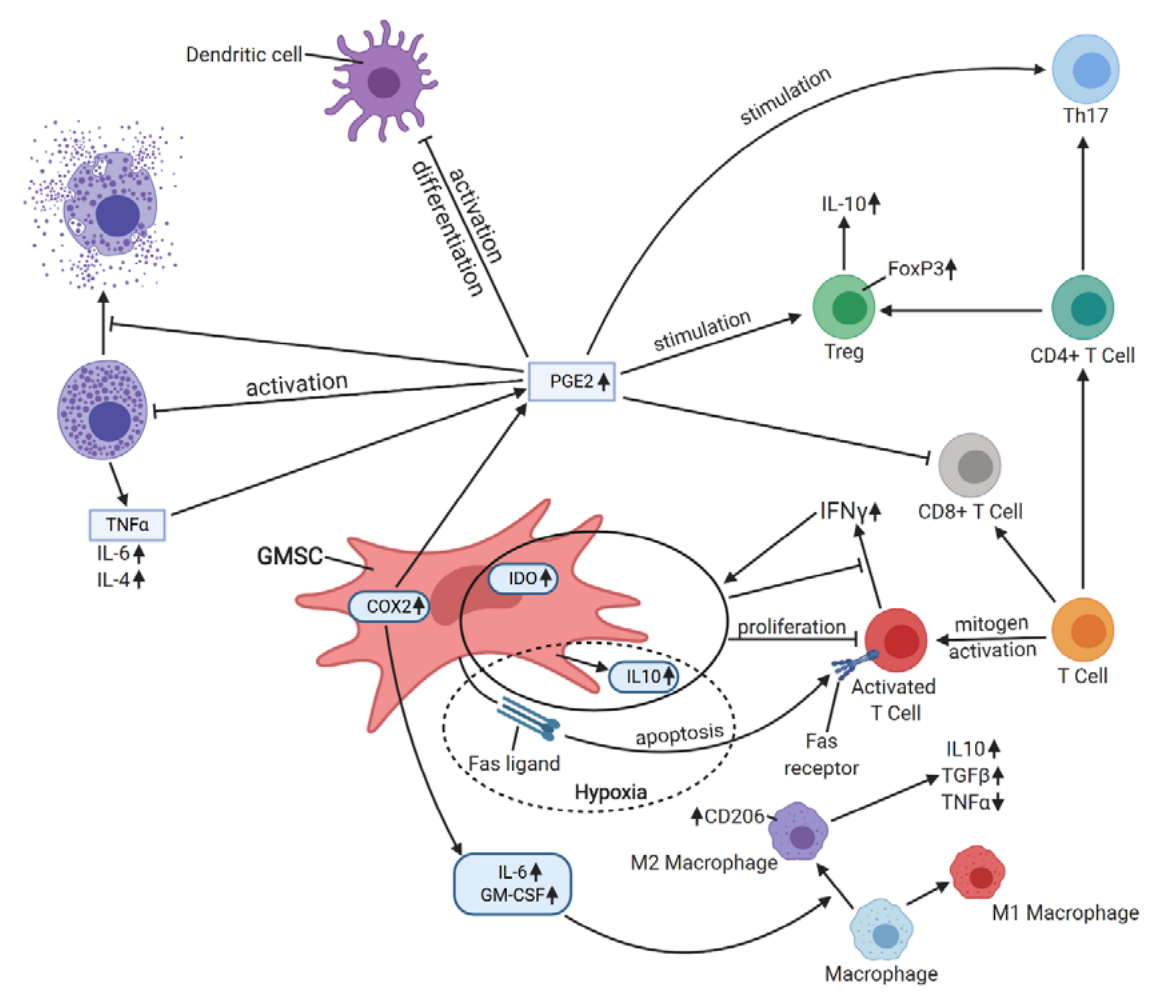

Figure 2. A schematic immunomodulatory activity of GMSCs. GMSCs exert apoptotic effects on T-cells via FasL/Fas pathway, and FasL expression and IL-10 secretion by GMSCs is enhanced by hypoxia. In response to IFN $\gamma$ produced by activated T cells, GMSCs secrete IDO and IL-10, which inhibit T cells' proliferation and IFN $\gamma$ secretion. GMSCs elicit M2 polarization of macrophages via secretion of IL-6 and GM-CSF, which results in an increased expression of CD206, higher secretion of IL- 6 and TGF $\beta$ and reduced production of TNF $\alpha$ by M2 macrophages. The activation and differentiation of dendritic cells is attenuated via PGE2-dependent mechanism, as well as the activation and degranulation of mast cells. Additionally, TNF $\alpha$ secreted by mast cells increases the production of PGE2 in GMSCs. PGE2 is also responsible for CD8+ T cells' inhibition and Treg and Th17 cells' stimulation. Abbreviations: IDO-indoleamine 2,3-dioxygenase, IL-10-interleukin 10, IL-6 -interleukin 6, IL-4-interleukin 4, FasL-Fas ligand, GM-CSF-granulocyte-macrophage colony-stimulating factor, COX2-cyclooxygenase 2, PGE2 - prostaglandin E2, IFN $\gamma$-interferon $\gamma$, TGF $\beta$-transforming growth factor $\beta, \mathrm{TNF} \alpha$-tumor necrosis factor $\alpha$, FOXP3 - forkhead box P3. Created with BioRender. 


\section{Preclinical Studies with GMSCs}

The number of promising studies with GMSCs was conducted on animal models in tissue regeneration, inflammatory- and immunologic-related disorders, and tongue squamous cell carcinoma, among others. Importantly, besides using GMSCs themselves, their conditioned media were also proven to exert therapeutic properties. In some of the studies, GMSCs were engineered using advanced techniques, such as encapsulation in alginate microspheres, seeding on various types of scaffolds or 3D bioprinting.

\subsection{Anticancer Therapies}

Mesenchymal stem cells have been shown to preferentially migrate towards tumors, possibly due to the enhanced inflammation in the tumor microenvironment, making them a promising tool in anticancer therapies [53]. However, there are conflicting reports in the literature about the potential role of MSC in tumor microenvironment. Some authors reported tumoricidal effects of MSCs, e.g., on lung cancer cells [54], whereas in case of a breast cancer, MSCs promoted cancer progression and metastasis [55]. Promoting of tumor growth and angiogenesis may be exerted via secretion of proangiogenic cytokines, such as IL-6, VEGF (vascular endothelial growth factor), or TGF $\beta$, by MSCs differentiated into cancer-associated fibroblasts [56,57]. MSCs were also reported to increase the level of lysyl oxidase, resulting in enhanced breast cancer metastasis [58]. Additionally, the vast immunomodulatory properties of MSCs may not necessarily be beneficial in terms of cancer. Patel et al. [59] reported that MSCs may protect breast cancer cell from immune clearance via inhibition of NK (natural killer) cells and cytotoxic T lymphocytes, while increasing the level of Treg cells. When it comes to the anticancer effect, it mainly indicates the mechanism of immune response modulation, regulation of cellular signaling, and apoptosis induction. BM-MSCs were reported to reduce colorectal cancer initiation and progression via reprogramming the macrophages to become regulatory cells associated with phagocytosis, lowering the inflammation level by decreasing local IL-6 concentration and decreasing Th17 cell activity [60]. Adipose tissue-derived MSCs, on the other hand, were shown to suppress growth of tumor cells due to IFN $\beta$ secretion [61]. The reason of such discrepancies in terms of MSCs influence on cancer is probably due to the fact that MSCs from different sources may exert various effects on cancer cells. Ji et al. [62] suggested that MSCs for anticancer therapy should be derived from the same tissue/organ origin as tumor cells and that they would restore altered homeostasis, exerting anticancer effect.

To date, only a few studies utilizing GMSCs in anticancer therapies have been published (summarized in Table 2), mostly focusing on oral carcinomas, mainly tongue squamous cell carcinoma (TSCC). Squamous cell carcinomas comprise $95 \%$ of all head and neck carcinomas, whereas oral squamous cell carcinomas constitute more than $90 \%$ of oral neoplasms [63]. Traditional therapy for squamous cell carcinomas includes surgical resection and postoperative radiation. Although the constant development occurs in traditional anticancer therapies, the 5-year survival rate for this type of cancer is only $50 \%$. Moreover, up to $30 \%$ of patients with TSCC exhibit metastatic lesions in the lymph nodes, even without the clinical signs of metastasis [64], clearly suggesting that another approaches must be undertaken to enhance the efficiency of cancer treatment. Ji et al. [62] cocultured GMSCs with two oral cancer cell lines-CAL27 and WSU-HN6, revealing that MSCs inhibited oral cancer cell growth in vitro. Moreover, their conditioned medium exerted the same effect, suggesting that soluble factors secreted by GMSCs (including IL-6, IL-8, and GM-CSF) may be responsible for such antiproliferative properties. Additionally, Western blotting revealed that GMSCs downregulated the proliferation-related gene expression in cancer cells (Bcl-2 and survivin), while upregulating apoptosis-related genes (Bax, cleaved caspase-3, and PARP). It was also suggested that GMSCs' conditioned medium deactivated the JNK, ERK, and STAT3 pathways associated with proliferation [62].

Engineering MSCs to express specific antitumor factors seems to be an interesting approach in anticancer therapies, because it could ensure sufficient level of given factor at the tumor site due 
to its long-term expression, which would not be possible via systemic administration. Methods of engineering GMSCs for their enhanced anticancer properties are presented in the Figure 3. Xia et al. [63] demonstrated that GMSCs migrate towards TSCC cell lines in a greater deal than towards 293T cells or culture medium. Therefore, they transduced GMSCs with the tumor necrosis factor-related apoptosis-inducing ligand (TRAIL), exhibiting antitumor properties. After the in vitro coculture of the transduced GMSCs and TSCC cell lines, the necrosis and apoptosis of tumor cells were increased. In vivo studies revealed that transduced GMSCs injected to nude mice systemically inhibit TSCC cell growth, and after the selective engraftment into tumor tissues, through the mechanism of apoptosis [63].

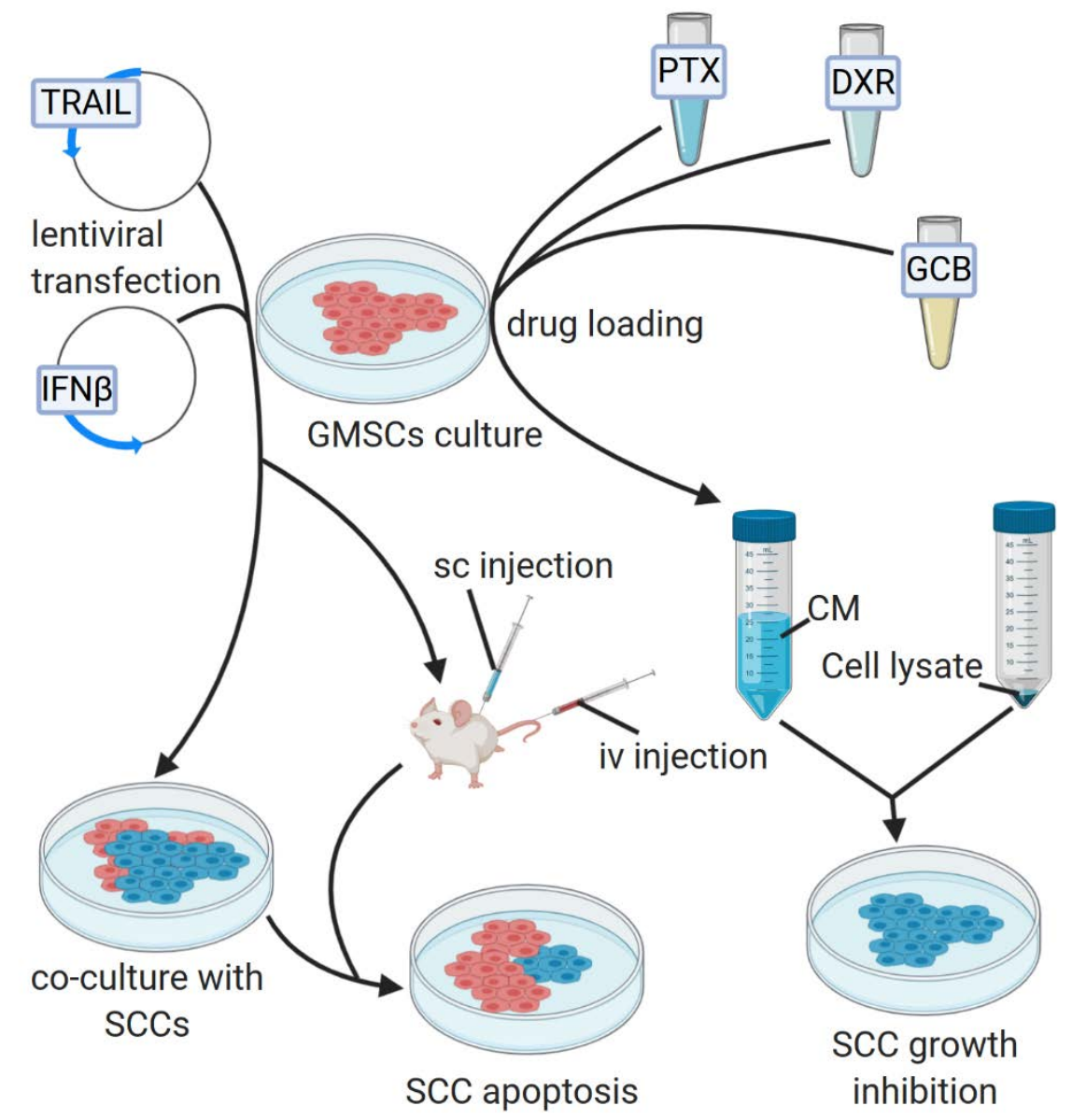

Figure 3. Overview of GMSCs engineering for enhanced anticancer properties. GMSCs may be transfected with lentiviral vectors, containing anticancer genes or loaded with anticancer drugs. Abbreviations: TRAIL—tumor necrosis factor-related apoptosis-inducing ligand; IFN $\beta$-interferon $\beta$; SCC—squamous carcinoma cell; $\mathrm{CM}$-culture medium; sc-subcutaneous; iv-intravenous; PTX—paclitaxel; DXR—doxorubicin; GCM—gemcitabine. Created with BioRender.

IFN $\beta$ is known for its antitumor properties, such as apoptosis induction or tumor cell growth inhibition, through the JAK/STAT1 intracellular signaling pathway, as well as the activation of the host's antitumor immune response [65]. The other types of MSCs transfected with IFN $\beta$ were already proven to exert anticancer properties, e.g., modified BM-MSCs-attenuated hepatocellular carcinoma, through inhibition by AKT/FOXO3a pathway [66], whereas the umbilical cord matrix-derived stem cells inhibited the growth of bronchioalveolar carcinoma by increasing apoptosis [67].

Du et al. [68] decided to undertake the same approach and transfected GMSCs with IFN $\beta$. The authors observed that such modified GMSCs significantly inhibited TSCC cells proliferation in vitro and led to their apoptosis. After an intravenous injection into the mouse TSCC model, the transfected GMSCs selectively engrafted in TSCC xenograft, which resulted in smaller tumor volume, 
due to inhibition of tumor cell proliferation, and lower number of Ki-67-positive cells, which is highly expressed in various tumor tissues and used as a marker of tumor cell proliferation [68].

Table 2. Overview of published studies utilizing GMSCs in anticancer therapies.

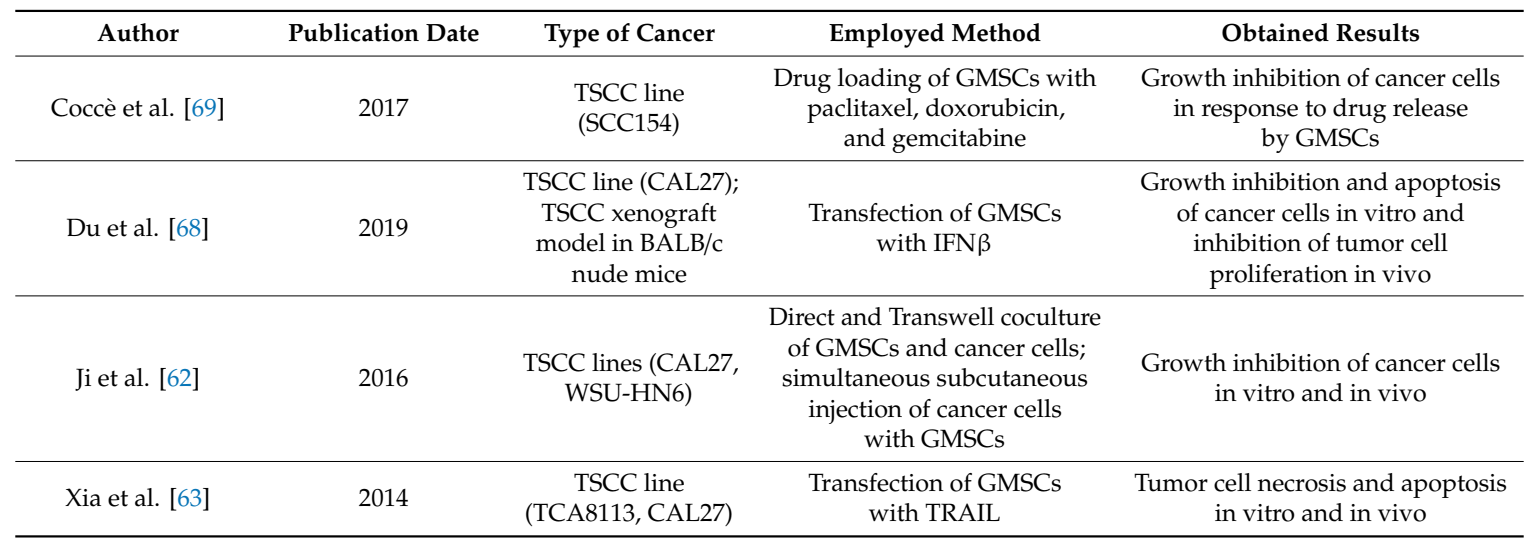

Coccè et al. [69] in vitro studies also revealed that GMSCs were able to uptake and release antineoplastic drugs, such as paclitaxel, doxorubicin, and gemcitabine, remaining less sensitive for their antiproliferative activity than cancer cells. The treatment of squamous carcinoma cells with the culture medium from drug-loaded GMSCs or their cell lysates resulted in dramatic inhibition of cancer cells growth, which was assessed via MTT assay.

Despite the lack of unanimity in indicating the role of MSCs in tumor promotion or suppression, it is significant that MSCs play a dynamic role within the tumor microenvironment. Further work is required to specify the intricate cross talk between MSCs and immune response at the tumor site.

\subsection{Oral Mucositis}

One of the major side effects of head and neck anticancer radio- and chemotherapy, affecting patients' life quality, is inflammation of oral and GI tract mucosa. Similar symptoms are observed in patients with host-versus-graft disease. Oral mucositis represents challenging and painful symptoms characterized by atrophy, erythema, and ulceration that can lead to severe complications such as malnutrition and secondary infections.

Zhang et al. [34] demonstrated in an in vivo murine model of chemotherapy-induced oral mucositis that spheroid cultures derived GMSCs displayed improved cell plasticity and homing to mucositic lesions. Additionally, systemic infusion of GMSCs in experimental colitis in murine model has significantly improved histopathological severity of the colonic inflammation and clinically suppressed the overall disease activity.

\subsection{Tissue Regeneration}

The use of GMSCs seems to be particularly beneficial in various tissue regeneration, given gingival robust healing properties. Zhang et al. [51] reported systemic infusion of GMSCs into an excisional full-thickness skin wound splinting mouse model, which resulted in accelerated skin wound closure compared to the controls without the treatment. Rapid re-epithelialization, collagen deposition, and angiogenesis were also observed. GMSCs were hypothesized to promote skin wound healing by suppressing inflammatory cell infiltration and proinflammatory cytokine production, as well as increasing IL-10 production [51]. GMSCs were also used in tendon tissue regeneration in a study by Moshaverinia et al. [70]. Cells were encapsulated in TGF- $\beta 3$-loaded RGD-coupled alginate microspheres and transplanted subcutaneously into immunocompromised mice, which resulted in wave-like aligned fibrils with tendon-like structure formation and ectopic neotendon regeneration as indicated by histological and immunohistochemical staining [70]. Ansari et al. [43] also encapsulated 
GMSCs in alginate microspheres loaded with myogenic differentiation cocktail and transplanted them subcutaneously into immunocompromised mice. Muscle-like structure formation were observed and histochemical, and immunofluorescent staining revealed the presence of myogenic cell-specific markers, such as Myosin II and MyoD, suggesting the possible use of GMSCs in muscle tissue regeneration [43].

Many studies aimed to utilize GMSCs in bone regeneration. Moshaverinia et al. [71], in another study, encapsulated GMSCs in a RGD-coupled alginate microspheres. Such encapsulated cells were transplanted into immunocompromised mice with 5-mm-diameter-critical-size calvarial defects, which resulted in bone fill. However, as indicated by microcomputed tomography analysis and histological staining, GMSCs were less efficient in bone regeneration than PDLSCs [71]. A systemic transplantation of GMSCs for bone regeneration was performed by $\mathrm{Xu}$ et al. [72] in C57BL/6J mice with defects in mandibular bone. The results revealed that GMSCs were able to home to the mandibular defect site and the bone regeneration was enhanced compared to the controls without the treatment [72]. Similar results were obtained by Wang et al. [73], who implanted GMSCs, seeded on type I collagen gel, into Sprague-Dawley rats with mandibular and calvarial defects. When coupled with poly-lactide (3D-PLA) scaffold, GMSCs or their conditioned medium exerted regenerative effect on calvarial defects in Wistar rats, as demonstrated by Diomede et al. [74]. GMSCs were also treated with an inhibitor of TGF $\beta$ signaling, which enhanced their osteogenic properties, resulting in new bone formation in minipig maxillary bone defect model [75].

GMSCs were also used for periodontal tissue regeneration. In a study by Sun et al. [76], GMSCs were transplanted systemically, through intravenous infusion, into mice with periodontitis. After the therapy, alveolar bone heights were increased and newly formed periodontal ligament and alveolar bone were reported [76]. Liu et al. [77] systemically transplanted GMSCs to hyperlipidemic mice with periodontitis, but they focused on their influence on lipid metabolism and inflammation. Besides the increased formation of the new bone and higher alveolar bone height, they observed a significant decrease in levels of triglyceride (TG), total cholesterol, low-density lipoprotein cholesterol (LDL), IL-6, $\mathrm{TNF} \alpha$, alveolar bone loss, and sterol regulatory element binding protein 1c (SREBP-1c). Moreover, the levels of high-density lipoprotein cholesterol (HDL), IL-10, and peroxisome proliferator-activated receptor $\alpha(\mathrm{PPAR} \alpha)$ were increased, resulting in attenuated inflammation and hyperlipidemia [77]. Even the conditioned medium from GMSCs was shown to promote periodontal regeneration in rats, which was due to the regulation of inflammatory factors and enhancement of osteogenic differentiation of bone progenitor cells [78]. Therefore, it seems that soluble factors secreted by GMSCs are sufficient for stimulation of periodontal regeneration.

In several studies, GMSCs were used for nervous tissue regeneration. Zhang et al. [79] printed nerve constructs from GMSCs spheroids in the absence of exogenous scaffolds, using a scaffold-free 3D bioprinter system. Such constructs were transplanted to rats with segmental defects in facial nerves, which resulted in their enhanced regeneration and functional recovery [79]. Mammana et al. [80] utilized GMSCs for spinal cord injury treatment in mice. They pretreated the cells with nanostructured liposomes enriched with MOR (moringin) and administered them intravenously, which restored spinal cord normal morphology via COX2, GFAP, IL-1 $\beta$, and IL-6 levels reduction. GMSCs also exerted aniapoptotic effects by decreasing levels of proapoptotic Bax, caspase 9, and caspase 3 [80]. Similar results were obtained by Rajan et al. [81], who utilized GMSCs-derived conditioned medium to treat scratch-injured murine motor neuron-like NSC-34 cells, which resulted in decreased levels of caspase 3, Bax, SOD-1 (superoxide dismutase 1), iNOS, and TNF $\alpha$ and increased levels of Bcl-2, IL-10, and neurotrophins, such as BDNF (brain-derived neurotrophic factor) and NT3 (neurotrophin 3). It was, therefore, hypothesized that conditioned medium from GMSCs may elicit neuroprotection and be useful in motor neuron injury treatment [81].

\subsection{Immunologic- and Inflammatory-Related Disorders}

Given the broad immunomodulatory properties of GMSCs, many authors have aimed to treat immunologic- and inflammatory-related disorders with the use of these cells in animal models. Murine 
contact hypersensitivity (CHS) is a model for human allergic contact dermatitis and both Su et al. [49] and Li et al. [82] demonstrated that systemic or local infusion of GMSCs mitigated CHS via decreased infiltration of inflammatory cells and suppression of inflammatory cytokines, which was due to the PGE2-dependent mechanisms. Rheumatoid arthritis is another condition, which could benefit from GMSCs therapy. After the infusion of GMSCs into collagen-induced arthritic mouse model, the severity of the disease decreased, i.e., the production of IFN $\gamma$ and IL-17A was downregulated, whereas the number of $\mathrm{CD}^{+} \mathrm{CD} 39^{+} \mathrm{FOXP3}^{+}$Treg cells increased, as indicated by Chen et al. [83]. Similar results were obtained by Gu et al. [84], who additionally revealed that such therapy induced T cell apoptosis via the FasL/Fas pathway, resulting in immune tolerance. Luo et al. [85], on the other hand, demonstrated that GMSCs transferred to collagen-induced arthritis mice suppress osteoclastogenesis and bone erosion, partly through CD39-adenosine signal pathway. The same signaling pathway was reported to be involved in GMSCs-mediated prevention of acute graft-versus-host-disease (GVHD) in mouse models, as indicated in studies by Huang et al. [86] and Ni et al. [87]. Immunomodulatory potential of GMSCs was also observed in the case of type I diabetes induced by streptozotocin in mice. After intraperitoneal injection, the levels of IL-17 and IFN $\gamma$ decreased in $\mathrm{CD}^{+}$and $\mathrm{CD} 8^{+} \mathrm{T}$ cells, both in spleen and lymph nodes, which resulted in delayed diabetes onset and ameliorated pathology scores in pancreas, suggesting a possible novel therapy for this autoimmune disease [88].

\section{Clinical Application in Stem Cell Therapies}

The clinicaltrials.gov website was subject to the search terms "Gingival Mesenchymal Stem Cells," "Gingival Stem Cells," and "GMSC" to uncover clinical trials utilizing stem cells derived from gingival tissue. To date, only three clinical trials with GMSCs are listed on clinicaltrials.gov website, with one completed (NCT03638154), one active, not yet recruiting (NCT03570333), and one of unknown status (NCT03137979). The completed study (NCT03638154) was randomized, double-blind trial that enrolled 20 participants with intrabony periodontal defects. The aim of the study was to evaluate regenerative potential of GMSCs carried in $\beta$-tricalcium phosphate scaffold, and the bone gain was measured using radiographic imaging, yet no results were posted. The second mentioned study (NCT03570333) was a single-blind nonrandomized trial that aimed to compare the regenerative and differentiation potential of GMSCs isolated from premolar and molar region of the mouth within the same patient. The third study (NCT03137979) was triple-blind randomized trial, enrolling 30 participants with periodontitis. Basically, 10 patients received GMSCs seeded on collagen scaffolds after open flap debridement, and the aim was to test the safety and efficacy of such transplantation, via evaluation of alveolar bone regeneration and adverse reaction, among others.

\section{Therapeutic Potential of GMSCs-Derived Exosomes}

Apart from GMSCs themselves, the GMSCs-derived exosomes may be used as a therapeutic tool. Exosomes are a subset of extracellular vesicles with a diameter of $40-160 \mathrm{~nm}$, containing DNA, RNA, lipids, metabolites, and proteins, that originate from the invagination of endosomal membrane [89]. Since they have the ability to transfer their cargo to recipient cells, they are assumed to play an important part in cell-to-cell communication and may be used as a drug delivery system [90]. Exosomes are released by most mammalian cells, both in pathological and physiological conditions, therefore, their application as diagnostic biomarkers has been proposed [91]. In terms of GMSCs-derived exosomes' therapeutic potential, only a few studies were conducted. In one of them, Rao et al. [92] reported their utilization in nerve regeneration, revealing that they were successful in promoting Schwann cell proliferation and axon growth in vitro. When combined with chitin conduits, these exosomes increased the number and diameter of nerve fibers and promoted myelin formation and motor function recovery in rats [92]. Shi et al. [93], on the other hand, combined exosomes from GMSCs with chitosan/silk hydrogel sponge and used them for treating wounds in a diabetic rat skin defect model. After the treatment, the deposition and remodeling of collagen and re-epithelialization occurred, and the microvessel and nerve density were increased compared to the control group [93]. In another study, 
GMSCs-derived exosomes were combined with small intestinal submucosa-extracellular matrix and transplanted into rats with a critical-sized tongue defect model, to examine the influence on taste bud regeneration [94]. Such therapy resulted in an increased expression of Shh, BDNF, CK14, CK8, and markers for type I, II, and II taste bud cells as compared to the controls, therefore facilitating taste bud regeneration and reinnervation, suggesting a possible application in tongue reconstruction [94]. The primary characteristics of exosomes, nanoscale size, membrane composition, stability and lack of toxicity, suggest innovative applications in clinical therapy. The possible clinical and preclinical application of GMSCs and their derivatives such as exosomes are presented schematically in the Figure 4.

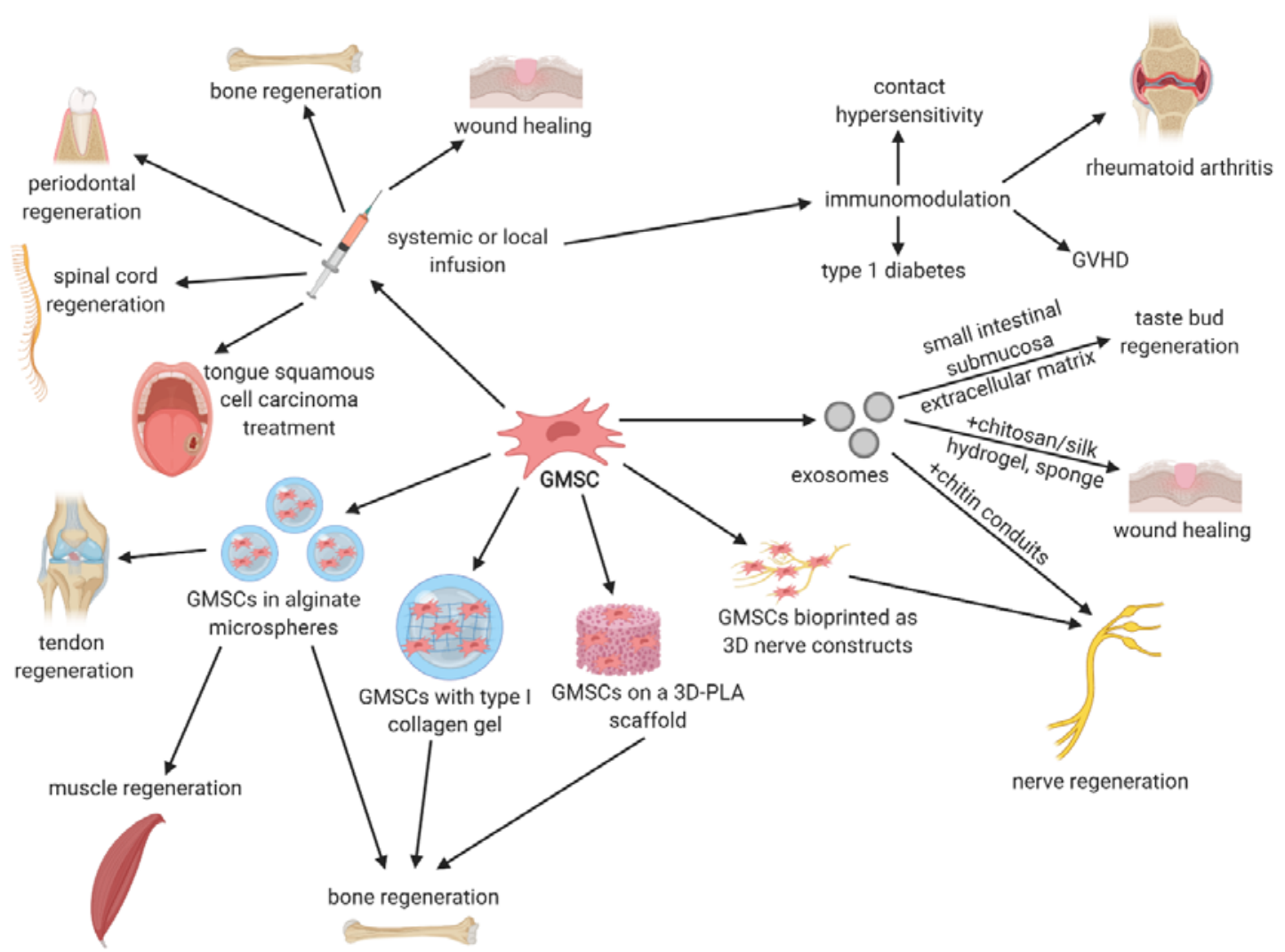

Figure 4. GMSCs may be injected, systemically or locally, or encapsulated in alginate microspheres, seeded on various types of scaffolds or gels, and bioprinted to facilitate bone, tendon, muscle, periodontal, nerve or spinal cord regeneration, wound healing, or tongue squamous cell carcinoma treatment, as well as in contact hypersensitivity, type 1 diabetes, graft-versus-host disease, or rheumatoid arthritis treatment. GMSCs-derived exosomes may be used for nerve or taste bud regeneration and wound healing. Created with BioRender.

\section{Conclusions}

The gingiva provides an alternative source of easily obtainable adult mesenchymal stem cells. They fulfill the minimal criteria for MSCs published by ISCT and are able to differentiate into cell lineages derived from all three primary germ layers in vitro, however in most cases, the in vivo differentiation was not confirmed. Their robust immunomodulatory potential was demonstrated both in vitro and in vivo and was exerted via direct cell-to-cell contact or soluble factor production, which indicates that not only GMSCs but also their conditioned media or their exosomes may be used in therapy. Indeed, such approach has been undertaken in several studies, providing promising results in terms of tissue regeneration and immunomodulation. GMSCs may also become a powerful tool in anticancer therapies, especially when engineered to express antitumor molecules. However, most of the studies utilizing GMSCs or their derivatives are at the preclinical stage. Although in many 
cases the results are promising, there is a need to conduct similar studies in humans to prove GMSCs' safety and efficacy, as the appropriate dosage or long-term fate of transplanted GMSCs in the recipient remains unclear.

Author Contributions: Conceptualization: K.S., H.P.-K., B.K., M.D.-K.; investigation: K.S., K.M., M.W., M.K.; writing-original draft: K.S.; writing-review \& editing: K.S., K.M., M.W., M.K., P.M.; validation: M.K., A.A.V., J.A.S., M.T.S., P.A.; resources: A.A.V., J.A.S., P.M.; supervision: P.M., M.T.S., P.A., J.M.J.; funding acquisition: J.M.J., B.K., M.D.-K.; project administration: H.P.-K., B.K., M.D.-K. All authors have read and agreed to the published version of the manuscript.

Funding: This research was funded by the Polish Ministry of Science and Higher Education, grant number 0070/DW/2018/02. The APC was funded by the Polish Ministry of Science and Higher Education.

Acknowledgments: This publication and its results are an outcome of a cooperation between Poznan University of Medical Sciences (Poznań, Poland) and Polish Ministry of Science and Higher Education, with Cellivia 3 S.A. (Poznań, Poland), as a part of the "Professional PhD" program. All figures presented in the manuscript were prepared by Maurycy Jankowski from Department of Anatomy, Poznan University of Medical Sciences.

Conflicts of Interest: The authors declare they have no conflicts of interest.

\section{References}

1. Uccelli, A.; Moretta, L.; Pistoia, V. Mesenchymal stem cells in health and disease. Nat. Rev. Immunol. 2008. [CrossRef] [PubMed]

2. Friedenstein, A.J.; Chailakhjan, R.K.; Lalykina, K.S. The Development of Fibroblast Colonies in Monolayer Cultures of Guinea-Pig Bone Marrow and Spleen Cells. Cell Prolif. 1970, 3, 393-403. [CrossRef] [PubMed]

3. Pittenger, M.F.; Mackay, A.M.; Beck, S.C.; Jaiswal, R.K.; Douglas, R.; Mosca, J.D.; Moorman, M.A.; Simonetti, D.W.; Craig, S.; Marshak, D.R. Multilineage potential of adult human mesenchymal stem cells. Science 1999. [CrossRef] [PubMed]

4. Gruber, H.E.; Deepe, R.; Hoelscher, G.L.; Ingram, J.A.; Norton, H.J.; Scannell, B.; Loeffler, B.J.; Zinchenko, N.; Hanley, E.N.; Tapp, H. Human adipose-derived mesenchymal stem cells: Direction to a phenotype sharing similarities with the disc, gene expression profiling, and coculture with human annulus cells. Tissue Eng. Part A 2010, 16, 2843-2860. [CrossRef]

5. In't Anker, P.S.; Scherjon, S.A.; Kleijburg-van der Keur, C.; de Groot-Swings, G.M.J.S.; Claas, F.H.J.; Fibbe, W.E.; Kanhai, H.H.H. Isolation of Mesenchymal Stem Cells of Fetal or Maternal Origin from Human Placenta. Stem Cells 2004. [CrossRef]

6. In't Anker, P.S.; Scherjon, S.A.; Kleijburg-van der Keur, C.; Noort, W.A.; Claas, F.H.J.; Willemze, R.; Fibbe, W.E.; Kanhai, H.H.H. Amniotic fluid as a novel source of mesenchymal stem cells for therapeutic transplantation. Blood 2003. [CrossRef]

7. Campagnoli, C.; Roberts, I.A.G.; Kumar, S.; Bennett, P.R.; Bellantuono, I.; Fisk, N.M. Identification of mesenchymal stem/progenitor cells in human first-trimester fetal blood, liver, and bone marrow. Blood 2001. [CrossRef]

8. Secco, M.; Zucconi, E.; Vieira, N.M.; Fogaça, L.L.Q.; Cerqueira, A.; Carvalho, M.D.F.; Jazedje, T.; Okamoto, O.K.; Muotri, A.R.; Zatz, M. Multipotent Stem Cells from Umbilical Cord: Cord Is Richer than Blood! Stem Cells 2008, 26, 146-150. [CrossRef]

9. Huang, G.; Ye, S.; Zhou, X.; Liu, D.; Ying, Q.L. Molecular basis of embryonic stem cell self-renewal: From signaling pathways to pluripotency network. Cell. Mol. Life Sci. 2015, 72, 1741-1757. [CrossRef]

10. Gronthos, S.; Mankani, M.; Brahim, J.; Robey, P.G.; Shi, S. Postnatal human dental pulp stem cells (DPSCs) in vitro and in vivo. Proc. Natl. Acad. Sci. USA 2000. [CrossRef]

11. Miura, M.; Gronthos, S.; Zhao, M.; Lu, B.; Fisher, L.W.; Robey, P.G.; Shi, S. SHED: Stem cells from human exfoliated deciduous teeth. Proc. Natl. Acad. Sci. USA 2003. [CrossRef] [PubMed]

12. Seo, B.M.; Miura, M.; Gronthos, S.; Bartold, P.M.; Batouli, S.; Brahim, J.; Young, M.; Robey, P.G.; Wang, C.Y.; Shi, S. Investigation of multipotent postnatal stem cells from human periodontal ligament. Lancet 2004. [CrossRef]

13. Morsczeck, C.; Götz, W.; Schierholz, J.; Zeilhofer, F.; Kühn, U.; Möhl, C.; Sippel, C.; Hoffmann, K.H. Isolation of precursor cells (PCs) from human dental follicle of wisdom teeth. Matrix Biol. 2005, 24, 155-165. [CrossRef] [PubMed] 
14. Matsubara, T.; Suardita, K.; Ishii, M.; Sugiyama, M.; Igarashi, A.; Oda, R.; Nishimura, M.; Saito, M.; Nakagawa, K.; Yamanaka, K.; et al. Alveolar bone marrow as a cell source for regenerative medicine: Differences between alveolar and iliac bone marrow stromal cells. J. Bone Miner. Res. 2005, 20, 399-409. [CrossRef]

15. Sonoyama, W.; Liu, Y.; Fang, D.; Yamaza, T.; Seo, B.M.; Zhang, C.; Liu, H.; Gronthos, S.; Wang, C.Y.; Shi, S.; et al. Mesenchymal stem cell-mediated functional tooth regeneration in Swine. PLoS ONE 2006. [CrossRef]

16. Ikeda, E.; Yagi, K.; Kojima, M.; Yagyuu, T.; Ohshima, A.; Sobajima, S.; Tadokoro, M.; Katsube, Y.; Isoda, K.; Kondoh, M.; et al. Multipotent cells from the human third molar: Feasibility of cell-based therapy for liver disease. Differentiation 2008. [CrossRef]

17. Zhang, Q.; Shi, S.; Liu, Y.; Uyanne, J.; Shi, Y.; Shi, S.; Le, A.D. Mesenchymal Stem Cells Derived from Human Gingiva Are Capable of Immunomodulatory Functions and Ameliorate Inflammation-Related Tissue Destruction in Experimental Colitis. J. Immunol. 2009, 183, 7787-7798. [CrossRef]

18. Xu, X.; Chen, C.; Akiyama, K.; Chai, Y.; Le, A.D.; Wang, Z.; Shi, S. Gingivae contain neural-crest- and mesoderm-derived mesenchymal stem cells. J. Dent. Res. 2013. [CrossRef]

19. Fawzy El-Sayed, K.M.; Dörfer, C.E. Gingival Mesenchymal Stem/Progenitor Cells: A Unique Tissue Engineering Gem. Stem Cells Int. 2016. [CrossRef]

20. Eslami, A.; Gallant-Behm, C.L.; Hart, D.A.; Wiebe, C.; Honardoust, D.; Gardner, H.; Häkkinen, L.; Larjava, H.S. Expression of integrin $\alpha \mathrm{v} \beta 6$ and TGF- $\beta$ in Scarless vs Scar-forming wound healing. J. Histochem. Cytochem. 2009. [CrossRef]

21. Lodi, D.; Iannitti, T.; Palmieri, B. Stem cells in clinical practice: Applications and warnings. J. Exp. Clin. Cancer Res. 2011. [CrossRef] [PubMed]

22. Mitrano, T.I.; Grob, M.S.; Carrión, F.; Nova-Lamperti, E.; Luz, P.A.; Fierro, F.S.; Quintero, A.; Chaparro, A.; Sanz, A. Culture and Characterization of Mesenchymal Stem Cells From Human Gingival Tissue. J. Periodontol. 2010. [CrossRef] [PubMed]

23. El-Sayed, K.M.F.; Paris, S.; Graetz, C.; Kassem, N.; Mekhemar, M.; Ungefroren, H.; Fändrich, F.; Dörfer, C. Isolation and characterisation of human gingival margin-derived STRO-1/MACS (+) and MACS (-) cell populations. Int. J. Oral Sci. 2015. [CrossRef]

24. El-Bialy, T.; Alhadlaq, A.; Wong, B.; Kucharski, C. Ultrasound effect on neural differentiation of gingival stem/progenitor cells. Ann. Biomed. Eng. 2014. [CrossRef] [PubMed]

25. Fournier, B.P.J.; Ferre, F.C.; Couty, L.; Lataillade, J.J.; Gourven, M.; Naveau, A.; Coulomb, B.; Lafont, A.; Gogly, B. Multipotent progenitor cells in gingival connective tissue. Tissue Eng. Part A 2010. [CrossRef] [PubMed]

26. Dominici, M.; Le Blanc, K.; Mueller, I.; Slaper-Cortenbach, I.; Marini, F.C.; Krause, D.S.; Deans, R.J.; Keating, A.; Prockop, D.J.; Horwitz, E.M. Minimal criteria for defining multipotent mesenchymal stromal cells. The International Society for Cellular Therapy position statement. Cytotherapy 2006, 8, 315-317. [CrossRef]

27. Ranga Rao, S.; Subbarayan, R. Passage-dependent expression of STRO-1 in human gingival mesenchymal stem cells. J. Cell. Biochem. 2019. [CrossRef]

28. Gao, Y.; Zhao, G.; Li, D.; Chen, X.; Pang, J.; Ke, J. Isolation and multiple differentiation potential assessment of human gingival mesenchymal stem cells. Int. J. Mol. Sci. 2014, 15, 20982-20996. [CrossRef]

29. Tang, L.; Li, N.; Xie, H.; Jin, Y. Characterization of mesenchymal stem cells from human normal and hyperplastic gingiva. J. Cell. Physiol. 2011. [CrossRef]

30. Tomar, G.B.; Srivastava, R.K.; Gupta, N.; Barhanpurkar, A.P.; Pote, S.T.; Jhaveri, H.M.; Mishra, G.C.; Wani, M.R. Human gingiva-derived mesenchymal stem cells are superior to bone marrow-derived mesenchymal stem cells for cell therapy in regenerative medicine. Biochem. Biophys. Res. Commun. 2010. [CrossRef]

31. Ge, S.; Mrozik, K.M.; Menicanin, D.; Gronthos, S.; Bartold, P.M. Isolation and characterization of mesenchymal stem cell-like cells from healthy and inflamed gingival tissue: Potential use for clinical therapy. Regen. Med. 2012. [CrossRef] [PubMed]

32. Jin, S.H.; Lee, J.E.; Yun, J.H.; Kim, I.; Ko, Y.; Park, J.B. Isolation and characterization of human mesenchymal stem cells from gingival connective tissue. J. Periodontal Res. 2015, 50, 461-467. [CrossRef] [PubMed]

33. Zhang, Q.Z.; Nguyen, A.L.; Yu, W.H.; Le, A.D. Human oral mucosa and gingiva: A unique reservoir for mesenchymal stem Cells. J. Dent. Res. 2012, 91, 1011-1018. [CrossRef] 
34. Zhang, Q.; Nguyen, A.L.; Shi, S.; Hill, C.; Wilder-Smith, P.; Krasieva, T.B.; Le, A.D. Three-dimensional spheroid culture of human gingiva-derived mesenchymal stem cells enhances mitigation of chemotherapy-induced oral mucositis. Stem Cells Dev. 2012. [CrossRef]

35. Wu, S.M.; Chiu, H.C.; Chin, Y.T.; Lin, H.Y.; Chiang, C.Y.; Tu, H.P.; Fu, M.M.J.; Fu, E. Effects of enamel matrix derivative on the proliferation and osteogenic differentiation of human gingival mesenchymal stem cells. Stem Cell Res. Ther. 2014. [CrossRef]

36. Sun, Q.; Nakata, H.; Yamamoto, M.; Kasugai, S.; Kuroda, S. Comparison of gingiva-derived and bone marrow mesenchymal stem cells for osteogenesis. J. Cell. Mol. Med. 2019. [CrossRef]

37. Lee, S.I.; Ko, Y.; Park, J.B. Evaluation of the osteogenic differentiation of gingiva-derived stem cells grown on culture plates or in stem cell spheroids: Comparison of two- and three-dimensional cultures. Exp. Ther. Med. 2017. [CrossRef]

38. Yuan, W.X.; Wang, X.X.; Zheng, D.H.; Ma, D.; Cui, Q.; Yang, F.; Zhang, J. Muscone promotes the adipogenic differentiation of human gingival mesenchymal stem cells by inhibiting the wnt $/ \beta$-catenin signaling pathway. Drug Des. Devel. Ther. 2019. [CrossRef]

39. Marynka-Kalmani, K.; Treves, S.; Yafee, M.; Rachima, H.; Gafni, Y.; Cohen, M.A.; Pitaru, S. The lamina propria of adult human oral mucosa harbors a novel stem cell population. Stem Cells 2010. [CrossRef] [PubMed]

40. Gugliandolo, A.; Diomede, F.; Scionti, D.; Bramanti, P.; Trubiani, O.; Mazzon, E. The Role of Hypoxia on the Neuronal Differentiation of Gingival Mesenchymal Stem Cells: A Transcriptional Study. Cell Transplant. 2019. [CrossRef]

41. Soundara Rajan, T.; Giacoppo, S.; Scionti, D.; Diomede, F.; Grassi, G.; Pollastro, F.; Piattelli, A.; Bramanti, P.; Mazzon, E.; Trubiani, O. Cannabidiol Activates Neuronal Precursor Genes in Human Gingival Mesenchymal Stromal Cells. J. Cell. Biochem. 2017. [CrossRef] [PubMed]

42. Rao, S.R.; Subbarayan, R.; Dinesh, M.G.; Arumugam, G.; Raja, S.T.K. Differentiation of human gingival mesenchymal stem cells into neuronal lineages in 3D bioconjugated injectable protein hydrogel construct for the management of neuronal disorder. Exp. Mol. Med. 2016. [CrossRef] [PubMed]

43. Ansari, S.; Chen, C.; Xu, X.; Annabi, N.; Zadeh, H.H.; Wu, B.M.; Khademhosseini, A.; Shi, S.; Moshaverinia, A. Muscle Tissue Engineering Using Gingival Mesenchymal Stem Cells Encapsulated in Alginate Hydrogels Containing Multiple Growth Factors. Ann. Biomed. Eng. 2016, 44, 1908-1920. [CrossRef] [PubMed]

44. Zhou, L.L.; Liu, W.; Wu, Y.M.; Sun, W.L.; Dörfer, C.E.; Fawzy El-Sayed, K.M. Oral Mesenchymal Stem/Progenitor Cells: The Immunomodulatory Masters. Stem Cells Int. 2020. [CrossRef]

45. Li, W.; Ren, G.; Huang, Y.; Su, J.; Han, Y.; Li, J.; Chen, X.; Cao, K.; Chen, Q.; Shou, P.; et al. Mesenchymal stem cells: A double-edged sword in regulating immune responses. Cell Death Differ. 2012. [CrossRef]

46. Davies, L.C.; Lönnies, H.; Locke, M.; Sundberg, B.; Rosendahl, K.; Götherström, C.; Le Blanc, K.; Stephens, P. Oral mucosal progenitor cells are potently immunosuppressive in a dose-independent manner. Stem Cells Dev. 2012. [CrossRef]

47. Jiang, C.M.; Liu, J.; Zhao, J.Y.; Xiao, L.; An, S.; Gou, Y.C.; Quan, H.X.; Cheng, Q.; Zhang, Y.L.; He, W.; et al. Effects of hypoxia on the immunomodulatory properties of human gingiva-derived mesenchymal stem cells. J. Dent. Res. 2015. [CrossRef]

48. Akiyama, K.; Chen, C.; Wang, D.; Xu, X.; Qu, C.; Yamaza, T.; Cai, T.; Chen, W.; Sun, L.; Shi, S. Mesenchymal-stem-cell-induced immunoregulation involves FAS-ligand-/FAS-mediated T cell apoptosis. Cell Stem Cell 2012. [CrossRef]

49. Su, W.R.; Zhang, Q.Z.; Shi, S.H.; Nguyen, A.L.; Le, A.D. Human gingiva-derived mesenchymal stromal cells attenuate contact hypersensitivity via prostaglandin E 2-dependent mechanisms. Stem Cells 2011. [CrossRef]

50. Sayed, B.A.; Christy, A.; Quirion, M.R.; Brown, M.A. The Master Switch: The Role of Mast Cells in Autoimmunity and Tolerance. Annu. Rev. Immunol. 2008. [CrossRef]

51. Zhang, Q.Z.; Su, W.R.; Shi, S.H.; Wilder-Smith, P.; Xiang, A.P.; Wong, A.; Nguyen, A.L.; Kwon, C.W.; Le, A.D. Human gingiva-derived mesenchymal stem cells elicit polarization of M2 macrophages and enhance cutaneous wound healing. Stem Cells 2010. [CrossRef]

52. Zhao, J.; Chen, J.; Huang, F.; Wang, J.; Su, W.; Zhou, J.; Qi, Q.; Cao, F.; Sun, B.; Liu, Z.; et al. Human gingiva tissue-derived MSC ameliorates immune-mediated bone marrow failure of aplastic anemia via suppression of Th1 and Th17 cells and enhancement of CD4 + Foxp3 + regulatory T cells differentiation. Am. J. Transl. Res. $2019,11,7627-7643$. 
53. Kidd, S.; Spaeth, E.; Dembinski, J.L.; Dietrich, M.; Watson, K.; Klopp, A.; Battula, V.L.; Weil, M.; Andreeff, M.; Marini, F.C. Direct evidence of mesenchymal stem cell tropism for tumor and wounding microenvironments using in vivo bioluminescent imaging. Stem Cells 2009, 27, 2614-2623. [CrossRef] [PubMed]

54. Liu, T.; Zhu, K.; Ke, C.; Yang, S.; Yang, F.; Li, Z.; Zhang, Z. Mesenchymal stem cells inhibited development of lung cancer induced by chemical carcinogens in a rat model. Am. J. Transl. Res. 2017, 9, 2891-2900. [PubMed]

55. Albarenque, S.M.; Zwacka, R.M.; Mohr, A. Both human and mouse mesenchymal stem cells promote breast cancer metastasis. Stem Cell Res. 2011. [CrossRef] [PubMed]

56. Walter, M.; Liang, S.; Ghosh, S.; Hornsby, P.J.; Li, R. Interleukin 6 secreted from adipose stromal cells promotes migration and invasion of breast cancer cells. Oncogene 2009, 28, 2745-2755. [CrossRef]

57. Zhang, T.; Lee, W.Y.W.; Rui, Y.F.; Cheng, T.Y.; Jiang, X.H.; Li, G. Bone marrow-derived mesenchymal stem cells promote growth and angiogenesis of breast and prostate tumors. Stem Cell Res. Ther. 2013, 4. [CrossRef]

58. El-Haibi, C.P.; Bell, G.W.; Zhang, J.; Collmann, A.Y.; Wood, D.; Scherber, C.M.; Csizmadia, E.; Mariani, O.; Zhu, C.; Campagne, A.; et al. Critical role for lysyl oxidase in mesenchymal stem cell-driven breast cancer malignancy. Proc. Natl. Acad. Sci. USA 2012, 109, 17460-17465. [CrossRef]

59. Patel, S.A.; Meyer, J.R.; Greco, S.J.; Corcoran, K.E.; Bryan, M.; Rameshwar, P. Mesenchymal Stem Cells Protect Breast Cancer Cells through Regulatory T Cells: Role of Mesenchymal Stem Cell-Derived TGF- $\beta$. J. Immunol. 2010, 184, 5885-5894. [CrossRef]

60. François, S.; Usunier, B.; Forgue-Lafitte, M.E.; L'Homme, B.; Benderitter, M.; Douay, L.; Gorin, N.C.; Larsen, A.K.; Chapel, A. Mesenchymal Stem Cell Administration Attenuates Colon Cancer Progression by Modulating the Immune Component within the Colorectal Tumor Microenvironment. Stem Cells Transl. Med. 2019, 8, 285-300. [CrossRef]

61. Ryu, H.; Oh, J.E.; Rhee, K.J.; Baik, S.K.; Kim, J.; Kang, S.J.; Sohn, J.H.; Choi, E.; Shin, H.C.; Kim, Y.M.; et al. Adipose tissue-derived mesenchymal stem cells cultured at high density express IFN- $\beta$ and suppress the growth of MCF-7 human breast cancer cells. Cancer Lett. 2014, 352, 220-227. [CrossRef] [PubMed]

62. Ji, X.; Zhang, Z.; Han, Y.; Song, J.; Xu, X.; Jin, J.; Su, S.; Mu, D.; Liu, X.; Xu, S.; et al. Mesenchymal stem cells derived from normal gingival tissue inhibit the proliferation of oral cancer cells in vitro and in vivo. Int. J. Oncol. 2016, 49, 2011-2022. [CrossRef] [PubMed]

63. Xia, L.; Peng, R.; Leng, W.; Jia, R.; Zeng, X.; Yang, X.; Fan, M. TRAIL-expressing gingival-derived mesenchymal stem cells inhibit tumorigenesis of tongue squamous cell carcinoma. J. Dent. Res. 2015. [CrossRef]

64. Sgaramella, N.; Gu, X.; Boldrup, L.; Coates, P.J.; Fahraeus, R.; Califano, L.; Tartaro, G.; Colella, G.; Spaak, L.N.; Strom, A.; et al. Searching For New Targets And Treatments In The Battle Against Squamous Cell Carcinoma Of The Head And Neck, With Specific Focus On Tumours Of The Tongue. Curr. Top. Med. Chem. 2018, 18. [CrossRef] [PubMed]

65. Imamura, Y.; Tashiro, H.; Tsend-Ayush, G.; Haruta, M.; Dashdemberel, N.; Komohara, Y.; Tsuboki, J.; Takaishi, K.; Ohba, T.; Nishimura, Y.; et al. Novel therapeutic strategies for advanced ovarian cancer by using induced pluripotent stem cell-derived myelomonocytic cells producing interferon beta. Cancer Sci. 2018, 109, 3403-3410. [CrossRef] [PubMed]

66. Xie, C.; Xie, D.Y.; Lin, B.L.; Zhang, G.L.; Wang, P.P.; Peng, L.; Gao, Z.L. Interferon- $\beta$ gene-modified human bone marrow mesenchymal stem cells attenuate hepatocellular carcinoma through inhibiting AKT/FOXO3a pathway. Br. J. Cancer 2013, 109, 1198-1205. [CrossRef]

67. Matsuzuka, T.; Rachakatla, R.S.; Doi, C.; Maurya, D.K.; Ohta, N.; Kawabata, A.; Pyle, M.M.; Pickel, L.; Reischman, J.; Marini, F.; et al. Human umbilical cord matrix-derived stem cells expressing interferon- $\beta$ gene significantly attenuate bronchioloalveolar carcinoma xenografts in SCID mice. Lung Cancer 2010, 70, $28-36$. [CrossRef]

68. Du, L.; Liang, Q.; Ge, S.; Yang, C.; Yang, P. The growth inhibitory effect of human gingiva-derived mesenchymal stromal cells expressing interferon- $\beta$ on tongue squamous cell carcinoma cells and xenograft model. Stem Cell Res. Ther. 2019. [CrossRef]

69. Coccè, V.; Farronato, D.; Brini, A.T.; Masia, C.; Giannì, A.B.; Piovani, G.; Sisto, F.; Alessandri, G.; Angiero, F.; Pessina, A. Drug Loaded Gingival Mesenchymal Stromal Cells (GinPa-MSCs) Inhibit In Vitro Proliferation of Oral Squamous Cell Carcinoma. Sci. Rep. 2017. [CrossRef]

70. Moshaverinia, A.; Xu, X.; Chen, C.; Ansari, S.; Zadeh, H.H.; Snead, M.L.; Shi, S. Application of stem cells derived from the periodontal ligament orgingival tissue sources for tendon tissue regeneration. Biomaterials 2014. [CrossRef] 
71. Moshaverinia, A.; Chen, C.; Xu, X.; Akiyama, K.; Ansari, S.; Zadeh, H.H.; Shi, S. Bone regeneration potential of stem cells derived from periodontal ligament or gingival tissue sources encapsulated in RGD-modified alginate scaffold. Tissue Eng. Part A 2014, 20, 611-621. [CrossRef] [PubMed]

72. Xu, Q.C.; Wang, Z.G.; Ji, Q.X.; Yu, X.B.; Xu, X.Y.; Yuan, C.Q.; Deng, J.; Yang, P.S. Systemically transplanted human gingiva-derived mesenchymal stem cells contributing to bone tissue regeneration. Int. J. Clin. Exp. Pathol. 2014, 7, 4922.

73. Wang, F.; Yu, M.; Yan, X.; Wen, Y.; Zeng, Q.; Yue, W.; Yang, P.; Pei, X. Gingiva-derived mesenchymal stem cell-mediated therapeutic approach for bone tissue regeneration. Stem Cells Dev. 2011. [CrossRef] [PubMed]

74. Diomede, F.; Gugliandolo, A.; Scionti, D.; Merciaro, I.; Cavalcanti, M.F.; Mazzon, E.; Trubiani, O. Biotherapeutic effect of gingival stem cells conditioned medium in bone tissue restoration. Int. J. Mol. Sci. 2018, 19, 329. [CrossRef]

75. Shi, A.; Heinayati, A.; Bao, D.; Liu, H.; Ding, X.; Tong, X.; Wang, L.; Wang, B.; Qin, H. Small molecule inhibitor of TGF- $\beta$ signaling enables robust osteogenesis of autologous GMSC s to successfully repair minipig severe maxillofacial bone defects. Stem Cell Res. Ther. 2019. [CrossRef]

76. Sun, W.; Wang, Z.; Xu, Q.; Sun, H.; Liu, X.; Yang, J.; Hong, R. The treatment of systematically transplanted gingival mesenchymal stem cells in periodontitis in mice. Exp. Ther. Med. 2019. [CrossRef]

77. Liu, X.; Wang, Z.; Song, W.; Sun, W.; Hong, R.; Pothukuchi, A.; Xu, Q. Systematically transplanted human gingiva-derived mesenchymal stem cells regulate lipid metabolism and inflammation in hyperlipidemic mice with periodontitis. Exp. Ther. Med. 2019. [CrossRef]

78. Qiu, J.; Wang, X.; Zhou, H.; Zhang, C.; Wang, Y.; Huang, J.; Liu, M.; Yang, P.; Song, A. Enhancement of periodontal tissue regeneration by conditioned media from gingiva-derived or periodontal ligament-derived mesenchymal stem cells: A comparative study in rats. Stem Cell Res. Ther. 2020. [CrossRef]

79. Zhang, Q.; Nguyen, P.D.; Shi, S.; Burrell, J.C.; Cullen, D.K.; Le, A.D. 3D bio-printed scaffold-free nerve constructs with human gingiva-derived mesenchymal stem cells promote rat facial nerve regeneration. Sci. Rep. 2018. [CrossRef]

80. Mammana, S.; Gugliandolo, A.; Cavalli, E.; Diomede, F.; Iori, R.; Zappacosta, R.; Bramanti, P.; Conti, P.; Fontana, A.; Pizzicannella, J.; et al. Human gingival mesenchymal stem cells pretreated with vesicular moringin nanostructures as a new therapeutic approach in a mouse model of spinal cord injury. J. Tissue Eng. Regen. Med. 2019. [CrossRef]

81. Rajan, T.S.; Diomede, F.; Bramanti, P.; Trubiani, O.; Mazzon, E. Conditioned medium from human gingival mesenchymal stem cells protects motor-neuron-like NSC-34 cells against scratch-injury-induced cell death. Int. J. Immunopathol. Pharmacol. 2017. [CrossRef] [PubMed]

82. Li, P.; Zhao, Y.; Ge, L. Therapeutic effects of human gingiva-derived mesenchymal stromal cells on murine contact hypersensitivity via prostaglandin E2-EP3 signaling. Stem Cell Res. Ther. 2016. [CrossRef] [PubMed]

83. Chen, M.; Su, W.; Lin, X.; Guo, Z.; Wang, J.; Zhang, Q.; Brand, D.; Ryffel, B.; Huang, J.; Liu, Z.; et al. Adoptive transfer of human gingiva-derived mesenchymal stem cells ameliorates collagen-induced arthritis via suppression of Th1 and Th17 cells and enhancement of regulatory T cell differentiation. Arthritis Rheum. 2013. [CrossRef] [PubMed]

84. Gu, Y.; Shi, S. Transplantation of gingiva-derived mesenchymal stem cells ameliorates collagen-induced arthritis. Arthritis Res. Ther. 2016. [CrossRef] [PubMed]

85. Luo, Y.; Wu, W.; Gu, J.; Zhang, X.; Dang, J.; Wang, J.; Zheng, Y.; Huang, F.; Yuan, J.; Xue, Y.; et al. Human gingival tissue-derived MSC suppress osteoclastogenesis and bone erosion via CD39-adenosine signal pathway in autoimmune arthritis. EBioMedicine 2019. [CrossRef] [PubMed]

86. Huang, F.; Chen, M.; Chen, W.; Gu, J.; Yuan, J.; Xue, Y.; Dang, J.; Su, W.; Wang, J.; Zadeh, H.H.; et al. Human gingiva-derived mesenchymal stem cells inhibit xeno-graft-versus-host disease via CD39-CD73-adenosine and IDO signals. Front. Immunol. 2017. [CrossRef]

87. Ni, X.; Xia, Y.; Zhou, S.; Peng, H.; Wu, X.; Lu, H.; Wang, H.; Liu, R.; Blazar, B.R.; Gu, J.; et al. Reduction in murine acute GVHD severity by human gingival tissue-derived mesenchymal stem cells via the CD39 pathways. Cell Death Dis. 2019. [CrossRef]

88. Zhang, W.; Zhou, L.; Dang, J.; Zhang, X.; Wang, J.; Chen, Y.; Liang, J.; Li, D.; Ma, J.; Yuan, J.; et al. Human Gingiva-Derived Mesenchymal Stem Cells Ameliorate Streptozoticin-induced T1DM in mice via Suppression of T effector cells and Up-regulating Treg Subsets. Sci. Rep. 2017. [CrossRef] 
89. Kalluri, R.; LeBleu, V.S. The biology, function, and biomedical applications of exosomes. Science 2020. [CrossRef]

90. Lane, R.E.; Korbie, D.; Anderson, W.; Vaidyanathan, R.; Trau, M. Analysis of exosome purification methods using a model liposome system and tunable-resistive pulse sensing. Sci. Rep. 2015. [CrossRef]

91. Tschuschke, M.; Kocherova, I.; Bryja, A.; Mozdziak, P.; Angelova Volponi, A.; Janowicz, K.; Sibiak, R.; Piotrowska-Kempisty, H.; Iżycki, D.; Bukowska, D.; et al. Inclusion Biogenesis, Methods of Isolation and Clinical Application of Human Cellular Exosomes. J. Clin. Med. 2020, 9, 436. [CrossRef] [PubMed]

92. Rao, F.; Zhang, D.; Fang, T.; Lu, C.; Wang, B.; Ding, X.; Wei, S.; Zhang, Y.; Pi, W.; Xu, H.; et al. Exosomes from human gingiva-derived mesenchymal stem cells combined with biodegradable chitin conduits promote rat sciatic nerve regeneration. Stem Cells Int. 2019. [CrossRef] [PubMed]

93. Shi, Q.; Qian, Z.; Liu, D.; Sun, J.; Wang, X.; Liu, H.; Xu, J.; Guo, X. GMSC-derived exosomes combined with a chitosan/silk hydrogel sponge accelerates wound healing in a diabetic rat skin defect model. Front. Physiol. 2017. [CrossRef] [PubMed]

94. Zhang, Y.; Shi, S.; Xu, Q.; Zhang, Q.; Shanti, R.M.; Le, A.D. SIS-ECM Laden with GMSC-Derived Exosomes Promote Taste Bud Regeneration. J. Dent. Res. 2019. [CrossRef]

(C) 2020 by the authors. Licensee MDPI, Basel, Switzerland. This article is an open access article distributed under the terms and conditions of the Creative Commons Attribution (CC BY) license (http://creativecommons.org/licenses/by/4.0/). 